Jpn. J. Med. Mycol.

Vol. 43, 1-4, 2002

ISSN 0916-4804

総 説

核 ribosome DNA の non-transcribed spacer 領域の

多型性に基づく病原真菌の分子疫学

一本邦分離の Arthroderma benhamiae についてー

望月隆

金沢医科大学皮唐科学教室

\begin{abstract}
要旨
極めて鋭敏な分子生物学的手法である non-transcribed spacer（NTS）領域を含む核 ribosome（r) DNAの制限酵 素分析法を用いて, 本邦で分離されたArthroderma（A.) benhamiae の分子疫学的検討を行った. 2001 年 3 月までに本邦 で分離され，同定が確定しているA. benhamiae は 13 株であり，その分離地域は兵庫 2 株, 埼玉 2 株, 島根 2 株, 岐阜 2 株, 東京 1 株, 長崎 4 株である. このうち, 島根, 長崎株はペットとその飼い主, 岐阜株は同一患者の手と顔の病巣, その他は個別に分離されている.この 13 株では島根 2 株, 埼玉のうち 1 株と長崎 4 株の計 7 株が同一の, また岐阜の 2 株が同じ分子型を示した. 残る 4 株は特徴的なパターンを示し，13 株は合計 6 分子型に分けられた. 1980 年以前に はA. benhamiae は本邦に分布しないとされていることから, 本邦にはこれ以降複数のクローンが移入され，これらが ペットの小動物の移動にともなって国内各地に拡散したと考えられた．また，ベルギー王立熱帯研究所から分与され た交配の基準株 4 株も合わせて検討したが，本邦分離株はべルギーの 4 株のいずれとも異なっていた，
\end{abstract}

Key words: 分子疫学 (molecular epidemiology), ribosomal DNA, non-transcribed spacer (NTS), strain identification, Arthroderma benhamiae

はじめに

近年多くの分子生物学的マーカーが白磨菌の研究に導 入されている ${ }^{1)}$ 。このうちの多くの手法が白痽菌の同定 に関するもので, これにより従来の培養法では同定不可 能な菌についても正確な同定が行えるようになった.し かし, 感染経路の解明に必要な菌株の識別に用いうるマー カーは少ない. 最近われわれは他の白敾菌の種内変異の 検出に用いられている non-transcribed spacer (NTS) 領域を含む核 ribosome（r） DNA の制限酵素分析法 (restriction fragment length polymorphisms, RFLP) ${ }^{2-4)}$ が Trichophyton (T.) mentagrophytes の有性世代のひとつ であるArthroderma（A.） benhamiaeにおいて菌株の識別 に有用であることを報告した ${ }^{5)}$.今回はその後 2001 年 3 月までに分離された株を含めて検討したのでその結果を 紹介するとともに，本法の有用性について述べる.

\section{菌株・方法}

\section{菌 株}

本邦で 2001 年 3 月までに分離された A. benhamiae 計 13 株（Table 1）を用いた。これらの株は交配試験により A. benhamiae であることが確認されている．また，交配 別刷請求先: 望月 隆 于920-0293 石川県河北郡内灘町大学 1-1 金沢医科大学波膚科学教室
試験のテスター株としてベルギー王立熱帯研究所から分 与された 4 株 (Americano-European race 2 株, African race 2 株）についても解析を行った.

\section{NTS 領域を含む rDNA の RFLP 分析}

DNAの抽出は以前の記述に従った2,3,5).すなわち液 体培地で培養した新鮮な菌約 $0.2 \mathrm{~g}$ を液体窒素で凍結し, 乳鉢と乳棒で粉砕し，これを $600 \mu l$ の抽出用 buffer (400 $\mathrm{mM}$ Tris- $\mathrm{HCl}, \mathrm{pH} 8,60 \mathrm{mM}$ EDTA, $150 \mathrm{mM} \mathrm{NaCl}$, $1 \%$ sodium dodecyl sulfate, $40 \mathrm{mg} / \mathrm{ml}$ proteinase $\mathrm{K}$ )

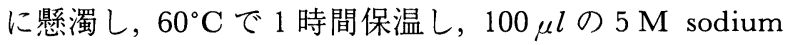
perchlorateを加え，さらに15分間保温した。これを chloroform で抽出し，上清を phenol-chloroform-isoamyl alcohol (25:24:1), 続いて chloroform で再度抽出後, 上清から DNA を isopropanol ならびに ethanol で沈澱, 洗浄し, 回収した. これを $200 \mu l$ の蒸留水に溶解し DNA 液とした. DNA 液の濃度はおおむね $0.5 \mu \mathrm{g} / \mu \mathrm{l}$ であった。 この DNA 液 $20 \mu l$ を制限酵素 EcoRI で消化し， $0.8 \%$ agarose 内で電気泳動後, DNA 断片を定法に従って Southern 法によってナイロン膜に転写した.これに18S rDNAの 3’末端から 5.8S rDNAを経て 28S rDNAの 5 , 末端に至る約 $1.2 \mathrm{~kb}$ の DNA を鋳型にしてDIG DNA Labeling kit ${ }^{\circledR}$ (Boehringer-Mannheim UK Ltd., Lewes, United Kingdom）で作製した digoxigenin 結合プロー ブ $2,3,5)$ (Fig. 1) を $62^{\circ} \mathrm{C}$ で数時間交雑させ，以下 DIG 
Table 1. Clinical isolates and tester strains of $A$. benhamiae used in the present study and their NTS typing

\begin{tabular}{|c|c|c|c|c|c|}
\hline \multicolumn{6}{|l|}{ Tester Strains } \\
\hline $\mathrm{KMU} 3153=\mathrm{X} 797 \mathrm{~A}$ & Americano-European race "+" & & & NTS I & \\
\hline KMU $3154=X 798 \mathrm{a}$ & Americano-European race "-" & & & NTS II & \\
\hline RV 30000 & African race "+" & & & NTS III & \\
\hline RV 30001 & African race "-" & & & NTS III & \\
\hline \multicolumn{6}{|l|}{ Clinical Isolates } \\
\hline VUT 97010 & Americano-European race "-" & rabbit & Hyogo & NTS IV & [10] \\
\hline VUT 00001 & Americano-European race “+” & guinea pig & Hyogo & NTS V & \\
\hline VUT 00002 & Americano-European race "-" & rabbit & Saitama & NTS VI & \\
\hline VUT 00003 & Americano-European race "-" & rabbit & Saitama & NTS VII & \\
\hline KMU $4136=\mathrm{G}$ & African race "-" & tinea corporis, neck & Shimane & NTS VII & [11] \\
\hline $\mathrm{KMU} 4137=\mathrm{H}$ & African race “-” & rabbit & Shimane & NTS VII & [11] \\
\hline KMU $4169=\mathrm{WF}$ & Americano-European race "-" & tinea corporis, face & Gifu & NTS VIII & [12] \\
\hline $\mathrm{KMU} 4170=\mathrm{WH}$ & Americano-European race "-" & tinea corporis, hand & Gifu & NTS VIII & [12] \\
\hline $\mathrm{KK}$ & Americano-European race "-" & kerion celsi & Tokyo & NTS IX & [13] \\
\hline NUD 1870 & Americano-European race “-” & tinea corporis & Nagasaki & NTS VII & \\
\hline NUD 1871 & Americano-European race "-" & tinea cruris & Nagasaki & NTS VII & \\
\hline NUD 1872 & Americano-European race “-” & rabbit & Nagasaki & NTS VII & \\
\hline NUD 10022 & Americano-European race "_" & tinea corporis & Nagasaki & NTS VII & \\
\hline
\end{tabular}

“-”: mating type -; “+”: mating type +; NTS I VIII: DNA type based on NTS polymorphisms; [ ]: references

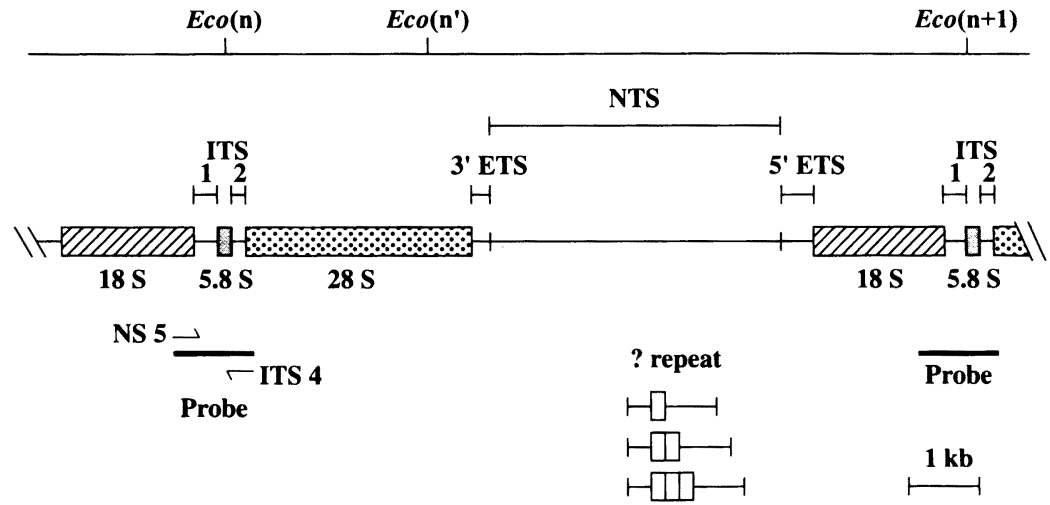

Fig. 1. The structure of ribosomal DNA repeats.

The length polymorphisms of non-transcribed spacer (NTS) between 28S and 18S ribosomal DNA, which were fragmented by EcoRI digestion, was detected by hybridization with a labeled probe.

Nucleic Acid Detection kit ${ }^{\circledR}$ (Boehringer-Mannheim UK Ltd.) によって peroxidase 法で発色して観察した.

\section{結 果}

NTS 領域を含む rDNA の RFLP 分析（Fig. 2) では, ペットとその飼い主から分離された島根株 2 株（KMU 4136, 4137), 長崎株 4 株 (NUD 株), 埼玉株 1 株 (VUT 00003）の計 7 株が同じパターンを示した. また同一患 者の手と顔の白癬病巣から分離された 2 株（KMU 4169, 4170) は同じパターンを示した. VUT 97010, VUT 00001, 00002, KK 株の 3 株はいずれもその株に特徵的なパター ンを示していた. 以上をまとめると, 本邦の 13 株はDNA タイプ IV から IXの6つの分子型に分けられた（Table 1). 外国由来のテスター株のうち, Americano-European race 2 株は各々別の, African race 2 株は互いに同一の パターンを示し， 4 株が 3 つの分子型に分けられた. 本 邦の分離株で外国株と同じ分子型を示したものはなかっ

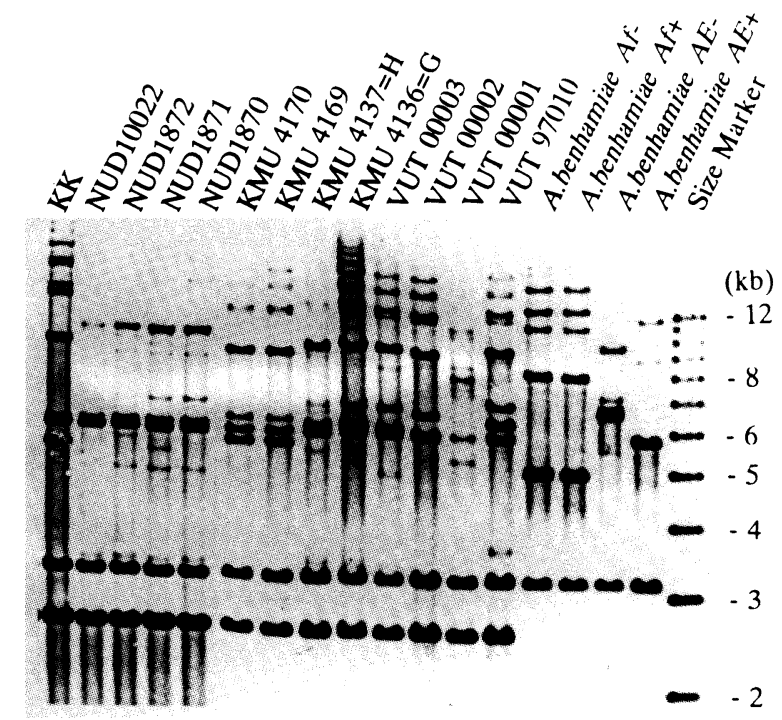

Fig. 2. The length polymorphisms of NTS (non-transcribed spacer). 
た.また再現性の確認のため，すべての株から別の機会 にDNA を抽出し，検討したが，パターンに差はみられ なかった。

\section{考察}

白癬菌 T. mentagrophytes は交配試験の結果, 3 種の有 性世代, すなわち A. benhamiae, A. vanbreuseghemii なら びにA. simii と, 有性世代が発見されていないいくつか の variety よりなる複合種 6,7$)$ であることが知られてい る. 本邦では有性世代のうちA. vanbreuseghemii のみが分 布し, A. benhamiae は分布しないと報告されていた8,9). しかし，1997年にウサギの病巣から A. benhamiae が分離 され10)，また1996年に島根で分離された 2 株がのちに A. benhamiae と同定された11) のをはじめとして, 最近ペッ トやその飼い主の白癬病巣から相次いで本菌が分離され ている ${ }^{12,13)}$. そのため本菌の感染経路や由来についての 疫学的検討は公衆衛生上, 重要な課題と考えられる.

今回用いた NTS 領域を含む rDNA の RFLP は $T$. rubrum $T$. mentagrophytes var. interdigitaleにおいて種 内変異を検出しうる鋭敏なマーカーとして知られてい $3^{2-4)}$.この方法で検出される多型は主にNTS 領域の長 さの変異に起因すると考えられる. この長さの変異は $T$. rubrum においては NTS 領域に存在する TRS-1 (200bp), TRS-2（77 bp）の二つの繰り返し配列のコピー数に基 づく3,4). その他，一つのコロニーでも複数の分子型の NTS 領域が含まれる可能性や, rDNA 内の EcoRI の切 断点の獲得, またもっとも 5 側に位置する $\mathrm{rDNA} の 工$ ニットとその上流に位置するE EcoRI 切断点の間に長さ の変異があると, これもあわせて検出されると考えられ る5).ささらに, EcoRI の切断点にメチル化が起これば切 断点の消失や, 不完全な消化が起こり, これが変異の原

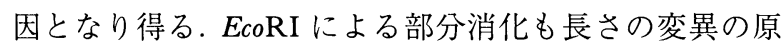
因になり得るが，RFLP パターンには再現性があるため， これが原因で多型が出現する可能性は少ない.ただし $T$. mentagrophytes complex においてはT. rubrumでみられる 繰り返し配列はまだ確認されていない.

先にわれわれはこれを用いて本邦で 2000 年 10 月まで に分離された $A$. benhamiae の 8 株は 5 つの分子型に分け られることを報告した5). 今回はその後分離された 5 株 を加えて検討したが，このうち長崎の 4 株は既に知られ ていた分子型を示し, 東京で分離された 1 株が新しい分 子型であった．従って合計 13 株が 6 つの分子型に分け られた．本法では，家族内，あるいは同じ患者の別々の 病巣から分離された菌株は同じ分子型を示す一方, 埼玉 の 3 株は同じ動物病院で分離されたものであるが, 菌 株ごとに別個な分子型が示された。よって，本法は $A$. benhamiae における囷株の識別に極めて有用であると考 えられた。

菌株の由来を考えると，タイプ VII の島根株は1996年 に分離され，これと同じ分子型の株は 2000 年に埼玉か ら，また 2000 年末から 2001 年初頭にかけ, 長崎の同じ 家庭から分離されている。これら 7 株は地域が離れてい
ること，発症にはいずれもペットのウサギが関与してい ることより,ペット動物の移送に伴って菌が移動したも のと推察された。また本菌は外国からの移入が予測され たが，外国株の検討が未だ十分でなく，移入は確認でき なかった．しかし1996年には島根で分離されているの で，それ以前に日本に移入されたものがすでに蔓延して おり，他の分子型を示す株が数次にわたり移入された可 能性がある. 今後, 国内の新規分離株に加えて国外の分 離株についても NTS の RFLP 法による検討を行うこと で，本邦での A. benhamiae の蔓延の実態と菌の由来が明 らかになると考えられる.

一方, 今回の夕イプ分けの結果と交配試験の判定に乘 離が見られた.A. benhamiaeには相互に交配が成立しに くいAfrican race と Americano-European race が存在 する6,14）と報告されているが，African race と判定され た島根株と Americano-European race と判定された埼 玉株，長崎株が同じ夕イプVIIに含まれていた。この理 由として，この方法では交配能力を司る遺伝子座と異な った部分の分子多型が検出されたと考えられた.しかし 交配試験における Americano-European race（本来の記 載では European race) と African raceの差は絶対的で はなく，平板上に形成された子囊果の数の差で鑑別され る14）ので, 交配試験はテスター株の性能力や培養条件 に大きく影響されると考えられる。したがって交配試験 は，このようにごく近縁の race 間の鑑別には適さない 可能性がある.さらに本邦分離株のうち 2 株 (KMU 4136, 4137）がミトコンドリア DNA の RFLP で従来の $A$. benhamiae と異なるパターンであったことが報告され1), 本 邦分離株には従来の Americano-European race, African race と異なる未知の race が含まれる可能性，あるいは 未知の race を構成する可能性がある. 本邦分離株と Americano-European race, African race との異同につ いては他の分子マーカーを用いて検討する必要がある.

\section{文献}

1）望月 隆，杉田泰之，槙村浩一, JA Kim, 加納 畦, 高 橋一朗, CN Okeke, 河崎昌子: 皮膚系状菌への分子生 物学の応用. 真菌誌 42: 81-86, 2001.

2) Jackson CJ, Barton RC, Evans EGV: Species identification and strain differentiation of dermatophyte fungi by analysis of ribosomal-DNA intergenic spacer regions. J Clin Microbiol 37: 931-936, 1999.

3) Jackson CJ, Barton RC, Kelly SL, Evans EGV: Strain identification of Trichophyton rubrum by specific amplification of subrepeat elements in the ribosomal DNA nontranscribed spacer. J Clin Microbiol 38: 4527-4534, 2000.

4) Jackson CJ: Molecular identification and strain typing of dermatophyte fungi. Jpn J Med Mycol 42: 7-10, 2001.

5) Mochizuki T, Kawasaki M, Ishizaki H, Kano R, Hasegawa A, Tosaki H, Fujihiro M: Molecular epidemiology of Arthroderma benhamiae, an emerging pathogen of dermatophytoses in Japan, by polymorphisms of the non-transcribed spacer region of the ribosomal DNA. 
J Derm Sci 27: 14-20, 2001.

6）高塩満男: 皮膚糸状菌の性世代とそれを基としたTrichophyton mentagrophytes の分類. 西日皮膚 38: 703-728，1976.

7) Takashio M: The Trichophyton mentagrophytes complex. In Recent Advances in Medical and Veterinary Mycology (Iwata K ed), p.271-276, Tokyo University Press, Tokyo, 1977.

8) Hironaga M, Watanabe S: Mating behavior of 334 Japanese isolates of Trichophyton mentagrophytes in relation to their ecological status. Mycologia 72: 1159-1170, 1980.

9) Watanabe S, Hironaga M: Differences or similarities of the clinical lesions produced by "+" and "- " types members of the "mentagrophytes" complex in Japan. In Sexuality and pathogenicity of fungi (Vanbreuseghem R, De Vroey Ch eds), p.83-96, Masson, Paris, 1981.

10) Kano R, Nakamura Y, Yasuda K, Watari T, Watanabe
S, Takahashi H, Tsujimoto $\mathrm{H}$, Hasegawa A: The first isolation of Arthroderma benhamiae in Japan. Microbiol Immunol 42: 575-578, 1998.

11) Kawasaki $M$, Aso $M$, Inoue $T$, Ohsawa $T$, Ishioka $S$, Mochizuki $\mathrm{T}$, Ishizaki $\mathrm{H}$ : Two cases of tinea corporis by infection from a rabbit with Arthroderma benhamiae. Jpn J Med Mycol 41: 263-267, 2000.

12）戸崎裕子，藤広満智子，望月 隆: ペットショップ店員 に生じたArthroderma benhamiae による手及び顔面白癬の 1 例. 西日皮膚 63: 542-545, 2001.

13）服部尚子，白井 明，外山啓子，金子健彦，槙村浩一： Kerion Celsi の 2 例一ペットより感染が疑われた小览例一. 真菌誌 41 (Suppl. 1): 97, 2000.

14) Takashio M: Observations of African and European starins of Arthroderma benhamiae. Int J Dermatol 13: 94$101,1974$.

\title{
Molecular Epidemiology of Japanese Isolates of Arthroderma benhamiae by Polymorphisms of Non-transcribed Spacer Region of the Ribosomal DNA
}

\author{
Takashi Mochizuki \\ Department of Dermatology, Kanazawa Medical University, \\ Ishikawa 920-0293, Japan
}

We made a molecular epidemiological study of Arthroderma benhamiae, a teleomorphic species of the Trichophyton mentagrophytes complex, using polymorphisms of the non-transcribed spacer region (NTS) of ribosomal DNA. Thirteen isolates - Hyogo 2 isolates, Saitama 2 isolates, Shimane 2 isolates, Tokyo 1 isolate, Nagasaki 4 isolates - were isolated from dermatophytoses lesions on pet animals and/or their owners, while 2 Gifu isolates were cultured from lesions on the face and hand of a pet shop worker. Along with the thirteen isolates, four tester strains for a mating study from Belgium were extracted total DNA and restriction fragment length polymorphisms (RFLP) of NTS were detected by a hybridization technique. The thirteen isolates were divided into 6 DNA types but none of them showed the same profile as the strains from Belgium. The most prevalent DNA type was composed of 7 isolates, from Saitama (1 isolate), Shimane (2 isolates) and Nagasaki (4 isolates) in 1996-2001. These isolates were considered to be a clone and spread by the transportation of pet animals. Since the species was not found in an intensive mating study carried out in 1980, several different clones of A. benhamiae may have been transported into Japan after that time. 